\title{
Just a few: rodents and lagomorphs in the Plio-Pleistocene fossil record of the Upper Valdarno Basin
}

\author{
LoRenzo RooK (*) \& Chiara Angelone (**)
}

\section{ABSTRACT}

The Plio-Pleistocene vertebrate fossil record of the Upper Valdarno Basin (Tuscany, Italy) is well known because of the large mammal collections. Although the small mammals have a documentation that is not even comparable with that of the large mammals; their record from Upper Valdarno Basin is known since early 1800's papers and includes a number of type specimen of species named by early researchers. We present here an overview of the rodents and lagomorphs distribution within the stratigraphic framework of the Upper Valdarno Basin.

KEY WORDS: Upper Valdarno Basin, Villányian, Biharian, Toringian, Pleistocene.

\section{INTRODUCTION}

The Upper Valdarno Basin record is celebrated for the well-known large mammal collections (CIOPPI \& Dominici, 2010; Dominici \& CiOPPI, 2012; RoOK et alii, 2013). On the other side, the small mammals have a record that is not even comparable to that of the large mammals: they are just a few. The small mammal record from Upper Valdarno Basin is limited, but it is known since early 1800's papers. CUVIER (1824) first recognized the presence of the fossil porcupine Hystrix in Upper Valdarno Basin, later on FALCONER $(1865,1868)$, FORSYTH MAJOR $(1875,1876,1884,1899,1902)$ and Bosco $(1898$, $1899 a, b)$ reported the occurrence of other rodents and lagomorphs.

A number of new species have been established on Upper Valdarno Basin rodents and lagomorphs by these early palaeontologists. Some are still valid:

1) the name Castor plicidens, for the Upper Valdarno Basin beaver, was used by FORSYTH MAJOR $(1875,1876)$ without a formal description. The species remained a "nomen nudum" until Bosco (1899a,b) analytically described the Upper Valdarno Basin beaver and formally named the species Castor plicidens. In a recent revision (BARISONE et alii, 2006) the Upper Valdano Basin beaver is taxonomically retained at the rank of subspecies (Castor fiber plicidens).

2) the vole Mimomys pliocaenicus: a fragment of left mandibular branch with $\mathbf{M}_{1}$ and incisor and a left $\mathbf{M}_{2}$, probably belonging to the same individual, from Castel-

(*) Dipartimento di Scienze della Terra, Università di Firenze. Via La Pira, 4 - 50125 Firenze (Italy). E-mail: lorenzo.rook@unifi.it

$(* *)$ Institut Català de Paleontologia Miquel Crusafont, Universitat Autònoma de Barcelona, Edifici ICP, Campus de la UAB s/n, 08193, Cerdanyola del Vallès, Barcelona (Spain). E-mail: angelone@ uniroma3.it franco di Sopra has been described as Arvicola pliocaenicus by FORSYTH MAJOR (1889) as collected from "Castelfranco di Sopra". Although the exact site of provenance is unknown, the locality is known by palaeontologists and "fossil-hunters" since $19^{\text {th }}$ century (RooK, 2012). Arvicola pliocaenicus was recombined by the same author (ForSYTH MAJOR, 1902) under the name Mimomys pliocaenicus, being the type species of genus Mimomys.

3) The specific name of the rabbit Oryctolagus valdarnensis was defined by WEITHOFER (1889) who ascribed to "Lepus valdarnensis" the leporids from Upper Valdarno Basin previously attributed to Lepus sp. by FORSYTH MAJOR $(1875,1876,1884)$. The Upper Valdarno Basin leporid remains have been then split into different species, and have a very long history of taxonomic controversies. According to a recent revision (ANGELONE \& ROOK, 2012) Oryctolagus valdarnensis is a valid species characterised by a very large morpho-dimensional variability and until now characteristic of the Late Villányan-Early Biharian (Early Pleistocene) of the Italian peninsula.

As a matter of fact, almost 200 years of palaeontological researches in the Upper Valdarno Basin have been elapsed, but the small mammal record has not increased too much, comprising just a few isolated findings (SALA \& MASINI unpublished, in MASINI \& TORRE, 1987; GHINASSI et alii, 2005; MAzZA et alii, 2006).

We provide here a short review of the Upper Valdarno Basin rodents and lagomorphs. In doing so, we will follow SALA \& MASINI (2007) and RoOK \& MARTÍNEZ-NAVARRO (2010) for biochronological references, whereas for the stratigraphic and chronologic setting of the Upper Valdarno Basin we refers to BoNINI et alii (2013), BRogI et alii (2013), FidOLINI \& ANDRETTA (2013), FIDOLINI et alii (2013), GHINASSI et alii (2013).

\section{GEOLOGICAL SETTING}

The Upper Valdarno Basin, located about $35 \mathrm{~km}$ South of Florence (fig. 1), is a NW-SE oriented tectonic depression bounded by the Chianti Mounts to the West and the Pratomagno Ridge to the East (MARTINI \& SAGRI, 1993; MARTINI et alii, 2001; FIDOLINI et alii, 2013). The basin shows an outstanding paleontological record including terrestrial vertebrates (Rook et alii, 2013, and reference therein), palinology (BERTINI, 2013, and reference therein), and non-marine molluscs (EsU \& GHINASSI, 2013).

The basin is filled with $550 \mathrm{~m}$ thick lacustrine and alluvial deposits (see Fidolini \& ANDREETTA, 2013; FIDOLINI et alii, 2013; GHINASSI et alii, 2013, for a more 


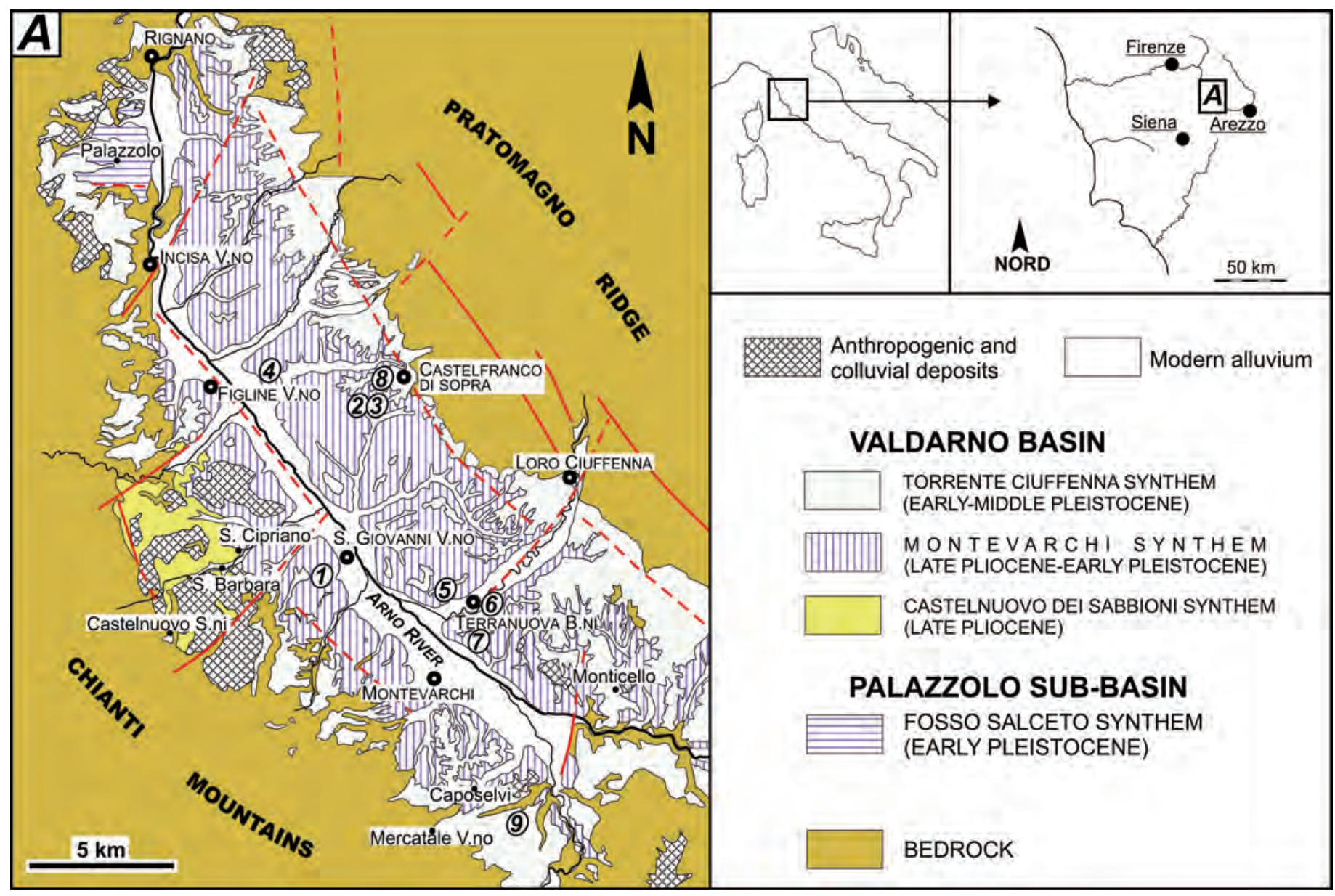

Fig. 1 - Location and geological sketch map of the Upper Valdarno Basin. Geographic location of the main fossiliferous sites with small mammals is shown: 1) Montecarlo; 2-3) Castelfranco di Sopra, and Le Mignaie; 4) Poggiorosso, and SoLaVa brick factory; 5) Case Inferno; 6) Terranova Bracciolini; 7) Le Strette al Tasso; 8) Poggitazzi; 9) Campitello quarry.

detailed reconstruction), which have been temporally constrained by detailed palaeomagnetic analysis closely integrated with mammal chronology (NAPOLEONE et alii, 2003; RoOK et alii, 2013) and radiometric dating (GHINASSI et alii, 2004).

The Upper Valdarno Basin fill succession is made of three synthems, which are, in stratigraphic order: Castelnuovo dei Sabbioni, Montevarchi, and Torrente Ciuffenna synthems (fig. 1). In the Palazzolo area, northwestern sector, a fourth synthem is recognised, Fosso Salceto Synthem, which is limited to this sector of the basin and is coeval with the Montevarchi Synthem (fig. 1). The Castelnuovo dei Sabbioni Synthem (Late Pliocene) consists of fluvio-deltaic gravel and sand, grading upward into lignitiferous lacustrine clay, in turn overlain by fluvio-deltaic sand (FIDOLINI et alii, 2013). Deposition of the Castelnuovo dei Sabbioni Synthem began during the Mammoth subchron (at about 3.3 Ma) and continued through the latest Gauss extending to the Late Pliocene. The Montevarchi Synthem (Late Pliocene-Early Pleistocene) consists of two portions separated by a minor unconformity passing basinward into a depositional surface (GHINASSI \& MAGI, 2004). The lower portion (Late Pliocene-Early Pleistocene) is made of alluvial-fan gravels grading upward into eolian-reworked alluvial sands. The upper portion (Early Pleistocene) is made of axial fluvial sand and mud interfingering with gravely alluvial-fans sourced from the margins (FIDOLINI et alii, 2013). The Montevarchi Synthem started to accumulate shortly before the Gauss-Matuyama boundary $(2.58 \mathrm{Ma})$ and finished few meters above the Olduvai subchron $(1.78 \mathrm{Ma})$. The Torrente Ciuffenna Synthem (Middle Pleistocene) includes fluvial gravel and sand in the central portion of the basin and alluvial-fan gravels and sand developed at the margins (FIDOLINI et alii, 2013). The magnetostratigraphic record in the Torrente Ciuffenna Synthem is fragmentary, mainly because of the prevalence of coarse-grained sediments, anyway the Matuyama-Brunhes boundary has been documented in the lower part of the synthem, indicating an age of the synthem spanning from the late Early Pleistocene to the Middle Pleistocene (fig. 2).

\section{UPPER VALDARNO SMALL MAMMALS}

\section{Castelnuovo dei Sabbioni Synthem}

No small mammal remains have been found associated to the early Villafranchian large mammal assemblages known from the Castelnuovo dei Sabbioni synthem (Gaville, Santa Barbara, etc.) (fig. 2; cfr. fig. 26 in Rook et alii, 2013). 


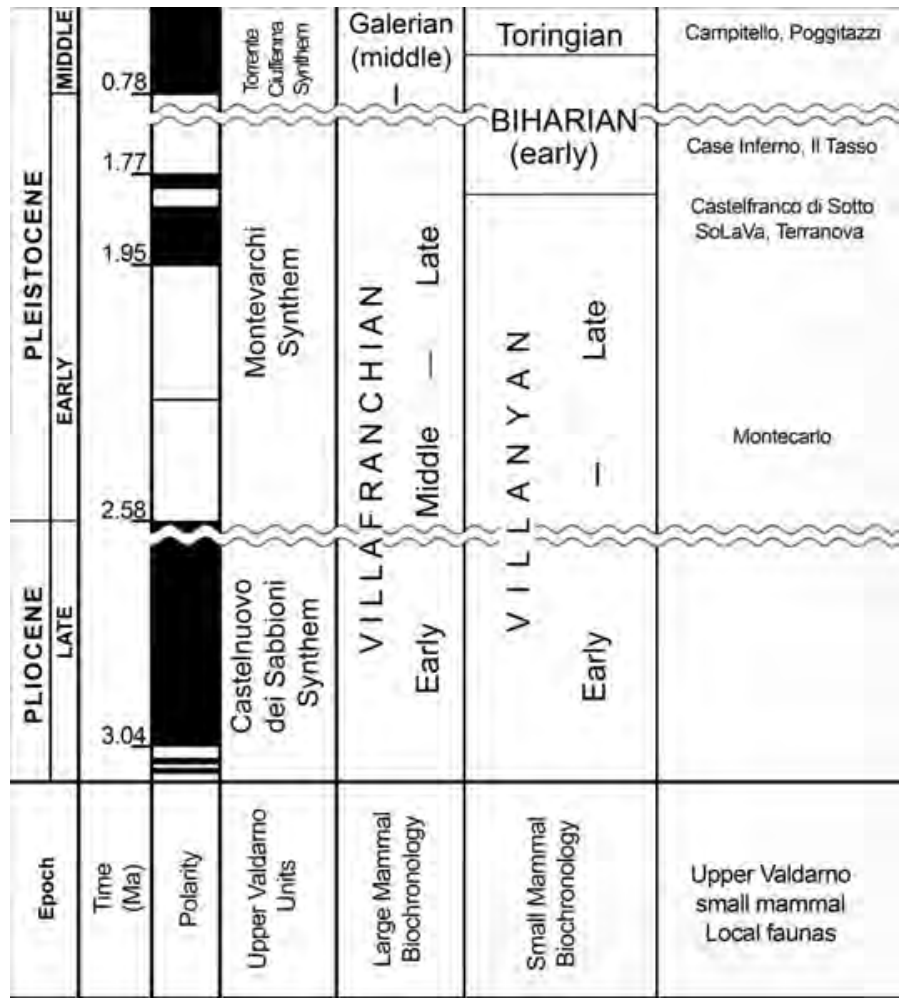

Fig. 2 - Upper Valdarno Basin stratigraphic units (from FIDOLINI et alii, 2013; NAPOLEONE et alii, 2003), combined with Large Mammal Biochronology, Small Mammal Biochronology and stratigraphic position of Upper Valdarno Basin local faunas mentioned in the text.

The early Villafranchian Large Mammal Age, corresponds to the Early Villányian (Late Pliocene) in small mammal chronology. In Italy the most representative Early Villányian assemblage is from Cascina Arondelli (Asti, Piedmont), a site that has yielded a rich fauna (KotSAKIs et alii, 2003). Albeit the Upper Valdarno Basin has no record of this small mammal biochron, other sites in Tuscany have a better documentation: i) Arcille (in southern Tuscany, Grosseto district; HÜRZELER \& ENGESSER, 1976) contained a small fauna that includes Mimomys hassiacus (MASINI \& TORRE, 1987); ii) the locality of San Giusto (in Lower Valdarno, Firenze district) yielded the type specimen of Mimomys stehlini (KoRmos, 1931). These assemblages are coeval with the large mammal assemblages of the Triversa Faunal Unit (F.U.; cfr. fig. 26 in Rook et alii, 2013) and are correlated to the Gauss Chron both in the Triversa area near Villafranca d'Asti (Piedmont) and within the Castelnuovo dei Sabbioni Synthem in the Upper Valdarno (NAPOLEONE et alii, 2003).

\section{Montevarchi Synthem}

The lower portion of the second sedimentary phase of Upper Valdarno Basin infilling (the Montevarchi Synthem) recently yielded a few vole remains allowing to identify the Late Villányian (base of the Early Pleistocene) Mimomys polonicus zone, in sediments characterised by reversed magnetization referred to the pre-Reunion interval of the Matuyama Chron (GHINASsI et alii, 2004, 2005). These findings are important because the Middle Villafranchian within the Upper Valdarno Basin tends to be really elusive (MASINI et alii, 1994). Before the discovery of the voles from Montecarlo (GHINASSI et alii, 2005), the occurrence of this biochronologic unit was inferred only because of the "biochronological" affinities of a few isolated remains with unknown provenance from old collections (MASINI et alii, 1994).

The upper part of the Montevarchi Synthem yielded the majority of the small mammals remains from the Upper Valdarno Basin, representing two different biochrons in the small mammal biochronologic scheme, the latest Villányian and the early Biharian, whose transition corresponds - within the Late Villafranchian large mammal Faunal Units - to the transition between Olivola and Tasso F.U. (fig. 2; see also fig. 26 in Rook et alii, 2013).

Castelfranco di Sopra site is the type locality of Mimomys pliocaenicus (FORSYTH MAJOR, 1889, 1902; TORRE, 1985), the vole who defines the homonymous zone of the latest Villányian (MASINI \& TORRE, 1987). Several local faunas bearing large mammals, grouped in the Olivola Faunal Unit, are indirectly referred to the $M$. pliocaenicus zone (TORRE et alii, 2001). The sediments outcropping in these localities are directly correlated with the postReunion Matuyama and the early part of Olduvai Subchron (NAPOLEONE et alii, 2003).

In addition to the Mimomys pliocaenicus type locality, further latest Villányian sites yielded other rodents and lagomorphs: the porcupine Hystrix refossa from Terranova (AzZAROLI, 1998); the beaver Castor fiber spp. from Poggiorosso and SoLaVa brick factory near Matassino (BARISONE et alii, 2006); the pika Prolagus aff. sorbinii from SoLaVa brick factory (RooK \& MASINI, 1990; ANGELONE \& RoOK, 2012); the rabbit Oryctolagus valdarnensis from Le Mignaie (ForTELEONI, 1971; ANGELONE \& RoOK, 2012).

Among sites celebrated for the large mammals belonging to the Tasso Faunal Unit, a few localities also yielded rodents and lagomorphs. Case Inferno (in literature also referred to as "Inferno", or "L'Inferno"), one of the most celebrated sites of the Tasso F.U., yielded remains of a vole described as Mimomys intermedius by KoRmos (1931) and later on revised as Mimomys savini by TORRE (1985). In addition to Case Inferno, an isolated $\mathrm{M}_{1}$ of Mimomys savini comes from "Le Strette presso il Tasso" (ToRre, 1985). The sediments cropping out at Case Inferno and Le Strette yielded faunal assemblages representing the Tasso F.U., and the occurrence of Mimomys savini suggests that these sites can be correlated with the early Biharian (MASINI \& TORRE, 1987).

Hystrix refossa is documented by two exquisitely preserved skulls (kept at the Museum of the Accademia Valdarnese del Poggio, Montevarchi) and by a number of fragmentary mandibles or isolated teeth (AzZAROLI, 1998; ROOK \& KOTSAKIS, 1994; VAN WEERS, 1994). BARISONE et alii (2005) recognised the occurrence of Castor fiber plicidens from San Giovanni Valdarno (correlated by the authors to Tasso F.U. sites). RooK \& MASINI (1990) reported the occurrence of a fragmentary mandible of the ochotonid Prolagus at Case Inferno (the specimen originally mentioned by ToBIEN, 1935). The latter has been revised by ANGELONE \& ROOK (2012) favouring an attribution to Prolagus aff. sorbinii. The same authors also revised the record of the rabbit Oryctolagus valdarnensis from Tasso F.U. sites in the collections of the Florence Museum and the Basel Naturhistorisches Museum. 
The sediments cropping out in this complex of localities have been magnetostragraphically correlated to the upper part of Olduvai and the very base of the following reverse interval of the Matuyama Chron (NAPOLEONE et alii, 2003).

\section{Torrente Ciuffenna Synthem}

The Middle Pleistocene Torrente Ciuffenna Synthem yielded a few rodents documenting the Early Toringian.

At Poggitazzi, a site in the area East of Figline Valdarno, where a scanty number of Galerian elements are known from old collections (AzZAROLI, 1984; MASINI et alii, 1994), Arvicola cantianus is recorded (TORRE, 1985), as well as an incisor of the porcupine Hystrix refossa (AzzAROLI, 1998).

Moreover, a relatively abundant small mammal sample has been recently recovered (MAzzA et alii, 2006) at Campitello quarry, in the Bucine area. The Campitello quarry small mammal assemblage includes Clethrionomys cf. glareolus, Arvicola cantianus, Microtus (Terricola) gr. multiplex-subterraneus, Microtus arvalis, and Apodemus sylvaticus.

Several characters of the Campitello faunal assemblage point towards an Early Toringian, late Middle Pleistocene age. Arvicola cantianus, showing a poorly differentiated tooth enamel, indicates a late, but not final, Middle Pleistocene; the occurrences of Microtus arvalis and of Microtus (Terricola) gr. multiplex-subterraneus are characteristics of Middle Pleistocene. Furthermore, a few teeth of an advanced form of Arvicola cantianus have then been recovered for higher stratigraphic position still in the Campitello succession, magnetostratigraphically correlated to the Brunhes Chron (MAZzA et alii, 2006; NAPOLEONE et alii, 2003).

\section{DISCUSSION}

Six families within Rodentia and Lagomorpha are known from the Upper Valdarno Basin record. Here follows a discussion of their current taxonomical status.

\section{Hystricidae}

VAN WEERS (1994) provided a revision of the European Plio-Pleistocene record of Hystrix refossa and clarified the taxonomic and nomenclatural status of this species. The species has been described from the fossil record under different names (including Hystrix etrusca). The Plio-Pleistocene species Hystrix refossa is characterised by a strongly built postcranial skeleton and hypsodont cheek teeth (VAN WEERS, 1994; ROOK \& SARDELLA, 2005). The species is documented in Upper Valdarno as occurring from in the upper part of the Montevarchi Synthem, both in the Late Villányian (Olivola F.U.) and in latest Villányian (Tasso F.U.). A single incisor attests to its occurrence also in the late Middle Pleistocene of the Torrente Ciuffenna Synthem (Azzarol, 1998). The latter single specimens, on the basis of its dimensions, allows to exclude the occurrence in Upper Valdarno of a second Middle Pleistocene species known in the fossil record of Europe: Hystrix (Acanthion) brachyura (a junior synonym of Hystrix vinogradovi; VAN WEERS, 2005; SALARI \& SARDELla, 2009).

\section{Castoridae}

The name Castor plicidens was published by FORSYTH MAJOR (1875) for an Upper Valdarno Basin beaver remain from San Giovanni Valdarno, without a formal description of the new species. A first preliminary description of $C$. plicidens was made by Bosco (1899a,b) who noticed that the most important characters distinguishing $C$. plicidens from other forms of living and fossil beavers are the pronounced secondary enamel folds on the premolar and molar occlusal surfaces. The species has been then debated in the literature; among others VIRET (1954) considered $C$. plicidens to be a valid species whereas LEHMANN (1957) believed the fossil record of the Middle and Late Villafranchian beavers better representing a subspecific differentiation of the extant species, thus C. fiber plicidens. BARISONE et alii (2006), studied the beaver from Pietrafitta (Late Villafranchian; Umbria, central Italy) and concluded that a specific distinction between Pietrafitta and Castor fiber (both fossil and living) populations is not statistically significant. However, the latter authors suggest a subspecific separation between Late Villafranchian beavers from Pietrafitta and $C$. fiber and conclude that the name $C$. fiber plicidens can be used for Pietrafitta and other Italian samples, including the San Giovanni Valdarno specimen.

A lower molar of a large rodent collected near Terranova Bracciolini was misidentified by Bosco (1899a) and described as the beaver Trogontherium cuvieri. The specimen (an isolated lower molar) actually belongs to the porcupine Hystrix refossa (Rook \& KotSAKIs, 1994). To date no fossil evidence support the occurrence of the large beaver Trogontherium south of the Alps.

\section{Arvicolidae}

The Upper Valdarno Basin records a succession of three Early Pleistocene arvicolid species within the Montevarchi Synthem: at Montecarlo the occurrence of the Late Villányian Mimomys polonicus (GHINASsI et alii, 2005) is recorded; the presence of the latest Villányian Mimomys pliocaenicus (TORRE, 1985) is only attested by the type specimen from Castelfranco di Sopra; the Early Biharian Mimomys savini (TORRE, 1985) is present in two sites belonging to the Tasso F.U.

The Torrente Ciuffenna Synthem documents the occurrence of Arvicola cantianus at two sites, Poggitazzi (TorRE, 1985) and at Campitello (MAZzA et alii, 2006). The latter site yielded a sample documenting the occurrence of other voles such as Clethrionomys cf. glareolus, Microtus (Terricola) gr. multiplex-subterraneus, and Microtus arvalis.

\section{Muridae}

The only murid documented within the Upper Valdarno Basin fossil record is Apodemus sylvaticus. Apodemus is one of the elements characterising the small mammal assemblage found at Campitello, a late Middle Pleistocene site within the Torrente Ciuffenna Synthem (MAzza et alii, 2006).

\section{Ochotonidae}

FALCONER (1868) first reported the occurrence of Lagomys (= Prolagus) among the vertebrates of Upper Val- 
darno Basin. The presence of this taxon was then confirmed by FORSYTH MAJOR (FORSYTH MAJOR in STOPPANI, 1872; data also reported in a synopsis, FORSYTH MaJOR, 1884; RoOK \& Alba, 2012). Neither FALCONER nor FORSYTH MAJOR figure the specimens, nor mention repository and inventory numbers thus we do not know if such specimens were lost or if their taxonomic assignment was reconsidered. Indeed in later lists Lagomys is substituted by Lepus (ForsYTH MAJOR, 1875, 1876, 1884). Bosco (1899a,b) reports and describes two lower right molariforms of Lagomys from Upper Valdarno Basin acquired by the Florence Museum in 1887. TOBIEN (1935) reports a Prolagus mandible from Upper Valdarno Basin kept within the Basel Naturhistorisches Museum collections, identified by RoOK \& MASINI (1990) with specimen NMBVA2246 from Case Inferno. The latter Authors also described a Prolagus fragmentary mandible from the SoLaVa brick factory, near Figline Valdarno. ANGELONE \& RooK (2012) provided a review of the Upper Valdarno Basin ocothonid record. They assigned Prolagus from Upper Valdarno Basin to Prolagus aff. sorbinii (a new species left for the moment in open nomenclature due to nomenclatorial problems still to be solved) distributed in the Late Pliocene-late Early Pleistocene of Tuscany, with possible extension to the Pliocene of NW Italy and central Western Europe (ANGELONE \& RoOK, 2012).

\section{Leporidae}

The first reports of leporids from Upper Valdarno Basin (attributed to Lepus sp.; ForSYTH MAJOR, 1875, $1876,1884)$ were followed by their ascription to a new species, L. valdarnensis (WEITHOFER, 1889), and were eventually split in two species (L. valdarnensis and L. etruscus, plus postcranial remains referred to Lepus sp.; Bosco, 1899a,b). FORSYTH MAJOR (1899) attributed all the Upper Valdarno Basin leporid remains to the genus Caprolagus whereas, fifty years later, VIRET (1954) recognized them as pertaining to Oryctolagus, putting them in synonymy with the Western European species O. lacosti. Such decision was followed in the literature from then on.

ANGELONE \& RoOK (2012) revising the Upper Valdarno Basin lagomorph record followed VIRET's (1954) attribution of the Upper Valdarno Basin leporids to the genus Oryctolagus, and considered O. valdarnensis a valid species, up to now known only in the Early Pleistocene (Late Villányan-Early Biharian) record of the Italian peninsula.

\section{CONCLUSIONS}

The small mammals record from Upper Valdarno Basin, although exceedingly limited when compared to the large mammals one (cfr. Rook et alii, 2013), includes a number of type specimens on which have been erected species whose names are still valid, and that are reference species in our understanding of continental stratigraphy and biochronology.

\section{ACKNOWLEDGEMENTS}

We are grateful to Mario Sagri and Massimiliano Ghinassi for inviting us to contribute within this special volume and for the critical reading of the manuscript. Elisabetta Cioppi and Stefano Dominici (Natural History Museum, University of Florence) and Loïc Costeur
(Naturhistorisches Museum, Basel) are gratefully acknowledged for access to collections and archives of their institutions. This paper is framed within a wider project on Late Neogene Vertebrate Palaeontology developed at the University of Florence (coordinator L.R.). For researches that resulted important background to this work C.A. received support from the SYNTHESYS Project http://www.synthesys. info/, financed by European Community Research Infrastructure Action under the FP6 "Structuring the European Research Area" (Project: HU-TAF-3145), and by the Spanish Ministerio de Economía y Competitividad (CGL2011-28681). Finally we thank the reviewers Loïc Costeur and Isaac Casanovas-Vilar for comments and suggestions that greatly improved the manuscript.

\section{REFERENCES}

ANGELONE C. \& Rook L. (2012) - Late Neogene and Quaternary lagomorphs from Tuscany: a revision based on specimens in Basel Naturhistorisches Museum and Florence University collections. Swiss J. Palaeont., 131, 127-145.

Azzaroli A. (1984) - On some Vertebrate remains of middle Pleistocene age from the Upper Valdarno and Val di Chiana, Tuscany. Palaeont. Ital., 73, 104-115.

Azzaroli A. (1998) - Hystrix etrusca Bosco, the late Villafranchian porcupine from the Upper Valdarno, central Italy. Palaeontogr. Ital., 85, 177-198.

Barisone G., Argenti P. \& Kotsakis T. (2006) - Plio-Pleistocene evolution of the genus Castor (Rodentia, Mammalia) in Europe: C. fiber plicidens of Pietrafitta (Perugia, Central Italy). Géobios, 39, 757-770.

Bertini A. (2013) - Climate and vegetation in the Upper Valdarno Basin (central Italy) as a response to Northern Hemisphere insolation forcing and regional tectonics in the late Pliocene-early Pleistocene. Ital. J. Geosci., 132, 137-148. doi: 10.3301/IJG.2012.18.

Bonini M., Moratti G., SANi F. \& BALESTRIERI M.L. (2013) - Compression-to-extension record in the Late Pliocene-Pleistocene Upper Valdarno Basin (Northern Apennines, Italy): structural and thermochronological constraints. Ital. J. Geosci., 132, 54-80. doi: 10.3301/IJG.2011.18.

Bosco C. (1898) - Hystrix etrusca n.sp. Palaeont. Ital., 4, 141-153. Bosco C. (1899a) - I roditori pliocenici del val d'Arno superiore. Palaeont. Ital., 5, 84-104.

Bosco C. (1899b) - I roditori pliocenici del val d'Arno superiore. Atti R. Accad. Lincei, 5, 261-265.

Brogi A., Fidolini F. \& LiotTA D. (2013) - Tectonic and sedimentary evolution of the Upper Valdarno Basin: new insights from the lacustrine S. Barbara Basin. Ital. J. Geosci., 132, 81-97. doi: 10.3301/IJG.2012.08.

Cioppi E. \& Dominici S. (2010) - Origin and development of the geological and palaeontological collections. In: Monechi S. \& Rook L. (eds.), Il Museo di Storia Naturale dell’Università di Firenze. Volume $3^{\circ}$ - Le collezioni geologiche e paleontologiche (pp. 19-55). Florence University Press, Firenze.

CUVIER G. (1824) - Recherches sur les ossemens fossiles, ou l'on rétablit les caractères de plusieurs animaux dont les révolutions du globe ont détruit les espèces. $5^{\text {th }}$ Volume. Paris, Dufour et d'Ocagne.

Dominici S. \& Cioppi E. (2012) - Evolutionary theory and the Florence Paleontological collection. Evol. Edu. Outreach, 5, 9-13.

Esu D. \& GHINAssi M. (2013) - The non-marine molluscs of the PlioPleistocene Upper Valdarno Basin (Tuscany, central Italy): depositional environments, palaeoecology and biochronology. Ital. J. Geosci., 132, 126-136. doi: 10.3301/IJG.2012.22.

FALCONER H. (1865) - On the species of Mastodon and Elephant occurring in the fossil State in Great Britain. (Read, 1857). Quarterly J. Geol. Soc., 13, 307-360; 21, 253-332.

FAlConer H. (1868) - The fossil Bovidae, Cervidae, and Antilopidae of India. In: Murchison C. (ed.), Paleontological memoirs and notes of the late Hugh Falconer "Fauna Antiqua Silvalensis", 1, 280-291.

Fidolini F. \& ANDREetTA A. (2013) - Integrating paleopedological and sedimentological data for paleoenvironmental reconstruction: examples from the Plio-Pleistocene Upper Valdarno Basin (Northern Apennines, Italy). Ital. J. Geosci., 132, 149-166. doi: 10.3301/ IJG.2012.26. 
Fidolini F., Ghinassi M., Magi M., PAPINI M. \& SAgRi M. (2013) The Plio-Pleistocene fluvio-lacustrine Upper Valdarno Basin (central Italy): Stratigraphy and Basin fill evolution. Ital. J. Geosci., 132, 13-32. doi: 10.3301/IJG.2012.06

ForSYTH MAJOR C.I. (1875) - Considerazioni sulla fauna dei mammiferi pliocenici e post pliocenici della Toscana. Atti Soc. Tosc. Sci. Nat., 1, 39-40.

FORSYTH MAJOR C.I. (1876) - Sul livello geologico a cui è d'ascriversi il così detto cranio dell'Olmo. Arch. Antropol. Etnol., 6, 336-347.

Forsyth MAJOR C.I. (1884) - On the Mammalian Fauna of the Val d'Arno. Quarterly J. Geol. Soc. London, 41, 1-8.

ForSYTH MAJOR C.I. (1899) - On fossil and recent Lagomorpha. Trans. Linnean Soc. London, s. 2, 7, 433-520.

Forsyth MAJOR C.I. (1902) - Some jaws and teeth of Pliocene voles (Mimomys gen. nov.) from the Norwich Crag at Thorpe, and from the Upper Val d'Arno. Proc. Zool. Soc. London, 1, 102-107.

FORTELEONI G. (1971) - The upper Valdarno lagomorph Lepus valdarnensis. Palaeont. Ital., 37, 55-68.

Ghinassi M., AbBazzi L., Esu D. \& Gaudant J. (2005) - Facies analisys, stratigraphy and Palaeontology (Molluscan and vertebrates) in the Upper Pliocene sandy flood-basin deposits of the Upper Valdarno Basin (Northern Apennines). Riv. It. Paleont. Strat., 111, 463-483.

Ghinassi M., Fidolini F., Magi M. \& SAgri M. (2013) - Depositional environments of the Plio-Pleistocene Upper Valdarno Basin (Tuscany, Italy). Ital. J. Geosci., 132, 33-53. doi: 10.3301/IJG.2012.07.

Ghinassi M. \& MAGI M. (2004) - Variazioni climatiche, tettoniche e sedimentazione al passaggio Pliocene Medio-Pliocene Superiore nel bacino del Valdarno Superiore (Appennino Settentrionale). Boll. Soc. Geol. It., 123, 301-310.

Ghinassi M., Magi M., SAGRI M. \& Singer B.S. (2004) - Arid climate 2.5Ma in the Plio-Pleistocene Valdarno Basin (Northern Apennines, Italy). Palaeogeogr., Palaeoclimat., Palaeoecol., 207, 37-57.

HÜRzeler J. \& ENGESSER B. (1976) - Les faunes de mammifères néogènes du Bassin de Baccinello (Grosseto, Italie). C. Rendus Acad. Sci. Paris, sér. II, 283, 333-336.

Kormos T. (1931) - Oberpliozäne Wühlmäuse von Senèze (Haute-Loir) und Val d'Arno (Toscana). Abh. Schweiz. Palaeont. Gesel., 51, 1-14.

Kotsakis T., AbBazzi L., Angelone C., Argenti P., Barisone G., FANFANi F., Marcolini F. \& MASINI F. (2003) - Plio-Pleistocene biogeography of Italian mainland micromammals. Deinsea, $\mathbf{1 0}$ 313-342.

Lehmann U. (1957) - Weitere Fossilfunde aus dem ältesten Pleistozän der Erpfinger Höhle (Schwabische Alb). Mitt. Geol. Staatsinst. Hamburg, 26, 60-99.

MARTINI I.P. \& SAGRI M. (1993) - Tectono-sedimentary characteristics of the late Miocene-Quaternary extensional basins of the Northern Apennines, Italy. Earth Sci. Rev., 34, 197-233.

Martini I.P., SAGRi M. \& Colella A. (2001) - Neogene-Quaternary Basins of the Inner Apennines and Calabrian Arc, Italy. In: Vai G.B. \& Martini I.P. (eds.), Anatomy of an Orogene. The Apennines and Adjacent Mediterranean Basins, 375-400, Dordrecht.

MASINI F., FicCARELli G. \& TORRE D. (1994) - Late Villafranchian ad the earliest Galerian mammal faunas from some intermontane basins of north-central Italy. Mem. Soc. Geol. It., 48, 381-389.

MAsini F. \& TORRE D. (1987) - Review of the Villafranchian Arvicolids of Italy. Geol. Romana, 26, 127-133.
Mazza P., Martini F., Sala B., Magi M., Colombini M.P., Giachi G., LANDUCCI F., LEMORINI C., MOdugno F. \& Ribechini E. (2006)A new Palaeolithic discovery: tar-hafted stone tools in a European Mid-Pleistocene bone-bearing bed. J. Archaeol. Sci., 33, 1810-1818.

Napoleone G., Albianelli A., Azzaroli A., Bertini A., Magi M. \& MazzinI M. (2003) - Calibration of the Upper Valdarno basin to the Plio-Pleistocene for correlating the Apennine continental sequences. Il Quaternario, 16, 131-166.

Rook L. \& AlBA D.M. (2012) - The pioneering paleoprimatologist Charles Immanuel Forsyth Major (1843-1923) and a Mesopithecus tooth from an unrecorded locality of Italy (?Casino Basin) in the Basel Naturhistorisches Museum. Boll. Soc. Paleont. It., 51, $1-6$.

Rook L. \& Kotsakis T. (1994) - On the presumed record of Trogontherium cuvieri Fischer from Upper Valdarno. Riv. It. Paleont. Strat., 100, 137-142.

RoOK L. \& MARTíNEZ-NAVARRo B. (2010) - Villafranchian: The long story of a Plio-Pleistocene European large mammal biochronologic unit. Quat. Int., 219, 134-144.

RoOK L. \& MASINI F. (1990) - Prolagus from the Upper Valdarno (faunal associations of the Olivola and Tasso Units, Late Villafranchian). Boll. Soc. Paleont. It., 29, 357-360.

RooK L. \& SARDELla R. (2005) - Hystrix refossa Gervais 1852, from Pirro Nord (Early Pleistocene, Southern Italy). Riv. It. Paleont. Strat., 111, 485-492.

Rook L., Croitor R., Delfino M., Ferretti M., Gallai G. \& PaVia M. (2013) - The Upper Valdarno Plio-Pleistocene vertebrate record: an historical overview, with notes on palaeobiology and stratigraphic significance of some important taxa. Ital. J. Geosci., 132, 104-125. doi: 10.3301/IJG.2012.16.

Sala B. \& Masini F. (2007) - Late Pliocene and Pleistocene small mammal chronology in the Italian peninsula. Quat. Int., 160, 4-16.

SALARI L. \& SARDELla R. (2009) - The Pleistocene porcupine Hystrix vinogradovi Argyropulo, 1941 in Italy. Boll. Soc. Paleont. It., 48, 123-127.

Stoppani C. (1872) - Corso di Geologia. Milano.

Tobien H. (1935) - Über die pleistozänen und postpleistozänen Prolagusformen Korsikas und Sardiniens. Ber. Naturf. Gesell. Freiburg im Brisgau, 34, 253-344.

TORRE D. (1985) - Mimomys savini and Arvicola cantiana in the Upper Valdarno (Italy). Eclogae geol. Helv., 78, 715-718.

Torre D., Abbazzi L., Bertini A., Fanfani F., Ficcarelli G., MasiNI F., MAZZA P. \& RoOK L. (2001) - Structural changes in Italian Late Pliocene-Pleistocene large mammal assemblages. Boll. Soc. Paleont. It., 40, 303-306.

VAN WeERs D.J. (1994) - The porcupine Hystrix refossa Gervais, 1852 from the Plio-Plesitocene of Europe, with notes on other fossil and extant species of the genus Hystrix. Scripta Geol., 106, 35-52.

VAN WeERS D.J. (2005) - A taxonomic revision of the Pleistocene Hystrix (Hystricidae, Rodentia) from Eurasia with notes on the evolution of the family. Contrib. Zool., 74, 301-312.

VIRET J. (1954) - Le loess a bancs durcis de Saint-Vallier (Drôme) et sa faune de mammifères villafranchiens. Nouv. Arch. Mus. Hist. Nat. Lyon, 4, 1-189.

WEITHOFER K.A. (1889) - Über die tertiären Landsaugethiere Italiens. Jahrb. kaiser.-kön. Geolog. Reich., 39, 80-81. 